\title{
Pleistocene sea level changes and glacial history of the Hornsund area, Svalbard
}

\section{HENRYK CHMAL}

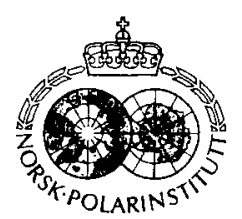

Chmal, H. 1987: Pleistocene sea level changes and glacial history of the Hornsund area, Svalbard. Polar Research 5 n.s., 269-270.

Henryk Chmal, Geographical Institute, University of Wroclaw, pl. Uniwersytecki 1, 50-137 Wroclaw, Poland.
The first radiocarbon datings of shells and whale bones from raised marine terraces of Hornsund (Birkenmajer \& Olsson 1970) showed that with regard to Quaternary geology South Spitsbergen is very different from the rest of Svalbard. Birkenmajer \& Olsson (1970) concluded that the 7.5-9.0 m terrace is about 9,400 years B.P. (uncorrected). This altitude is unusually low in comparison with other Svalbard regions where in the Preboreal-Boreal period the relative sea-level was $30-50 \mathrm{~m}$ or even $70 \mathrm{~m}$ higher than today (Salvigsen 1981). On the other hand, in the Hornsund area very high terraces were recorded. Werenskiold (1922) reported the existence of a $340 \mathrm{~m}$ terrace in Sørkapp Land. In Steinvikdalen, Jahn (1959) found a well developed pebble beach at $200-230 \mathrm{~m}$ level as well as evidence of sea washing reaching $275 \mathrm{~m}$ a.s.1.

The geochronological interpretation of marine and glacial deposits of the Hornsund area in this paper is based on geomorphological investigations and new radiocarbon, and TL dates.

\section{Marine terraces}

The age of the 7-9 $\mathrm{m}$ terrace has been determined by comparing radiocarbon datings from three sites. On Store Dunøya, below a $2 \mathrm{~m}$ layer of upper pebbles, peat was found and dated at 7,250 years B.P. In Nottinghambukta, in the lower part of an exposed section in the $7 \mathrm{~m}$ terrace there is sea tangle (Laminaria) which has been dated at 7,690 \pm 90 years B.P. The upper part of the section consists of pebbles with shells dated at $7,230 \pm 50$ years B.P. In Burgerbukta, on the surface of the $9 \mathrm{~m}$ terrace a piece of driftwood was found and dated at $5,050 \pm 60$ years B.P. The samples have been dated by M. Pazdur at Gliwice.

The interpretation of these datings is as follows: The deposits of the 7-9 $\mathrm{m}$ terrace reflect a marine transgression which lasted from about 7,200 to 5,000 years B.P. This transgression reached the $9 \mathrm{~m}$ level which the shore had passed during the regression 9,400 years B.P. (Birkenmajer \& Olsson 1970). During the period $8.000-7,200$ years B.P. the sea oscillated at a level of $1-$ $4 \mathrm{~m}$ a.s.l. Which is the highest level reached by the sea during the Late Vistulian (=Weichselian)-Early Holocene time? The shoreline corresponding to this level has been determined on the basis of detailed geomorphological studies, and it is $25 \mathrm{~m}$ in Hornsund and $32 \mathrm{~m}$ in the area between Torellbreen and Orvindalen. If the Early Holocene emergence of Svalbard is the result of a glacio-isostatic effect, then this effect was weakest in Hornsund. Hence it may be concluded that during the Main Vistulian $(18,000$ years B.P.) this region was the one least loaded with ice
The Middle-Vistulian marine transgression, about 45,000 27,000 years B.P., is known from many regions in Svalbard. Based on geomorphological observations we may conclude that at that time the sea in the Hornsund region reached a maximum level of $38-42 \mathrm{~m}$. In Turrsjødalen the $38 \mathrm{~m}$ terrace is built of deposits which originally made a sandur. It is cut off by a $7 \mathrm{~m}$ cliff which could have developed only during the Early Holocene marine transgression. Thus, the $38 \mathrm{~m}$ terrace is probably of a Vistulian age. The thermoluminescence (TL) datings suggested the age of this terrace to be $27,000 \pm 4,000$ years (dated by $\mathrm{J}$. Butrym at Lublin). The altitude of the Middle-Vistulian shoreline is rather small. Hence we may suppose that the glaciers during Early Vistulian and Main Vistulian were small as well.

The uppermost marine terraces occur in the Hornsund area at an altitude of $220-230 \mathrm{~m}$. Starting from Steinvikdalen we traced the highest shoreline along the west coast of Spitsbergen, and this level descends northwards. At the mouth of Bellsund it is about $120 \mathrm{~m}$. It should be noted that Mangerud et al. (this volume) consider these 'terraces' to be much older rock platforms of uncertain origin.

If we assume the local elevation of this shore level to be proportional to the thickness of the ice that covered the land during the corresponding glaciation, we might infer that the Hornsund area was the centre of a thick ice sheet during that glaciation. In accordance with former suggestions, this glaciation must be of Pre-Vistulian age, probably of Late Saalian age. A similar opinion was presented by Feyling-Hanssen \& Ulleberg (1984) for the Sarsbukta area.

\section{Glacial deposits}

In the large valleys of the Hornsund region only one type of basal till was observed lying on bedrock. Likewise, on the bottom of the Hornsund fjord only basal till occurs, covered by sandy and muddy deposits of a thickness of several dozen meters (Zalewski et al. 1984). In the large valleys the basal till is reworked by the sea to $120-230 \mathrm{~m}$ level. Thus, the basal till represents a record of the great Pre-Vistulian glaciation of the Hornsund area.

Counterparts of the upper Vistulian till, known from other regions of Spitsbergen (Landvik \& Salvigsen 1985), can in the Hornsund area only be found in small, nonglaciated cirques and in the glacier forefields. Also the moraines of no longer existing slope glaciers as well as those of rock glaciers may be regarded as corresponding with the upper till. The Vistulian till never extends more than $1 \mathrm{~km}$ outside the ice-cored moraines from 
the Little Ice Age. In Burgerbukta we can prove that the Mühlbacher, Kvalfangar and Wiber glacier group extended further during the Little Ice Age than during the Main Vistulian.

\section{References}

Birkenmajer, K. \& Olsson, 1. U. 1970: Radiocarbon dating of raised marine terraces at Hornsund, Spitsbergen, and the problem of land uplift. Norsk Polarinstitut Arbok 1969. 1743.

Feyling-Hanssen, R. \& Ulleberg, K. 1984: A Tertiary-Quaternary section at Sarsbukta, Spitsbergen, Svalbard, and its foraminifera. Polar Research 2 n.s. , 77-106.
Jahn, A. 1959: The raised shorelines and beaches in Hornsund and the problem of postglacial vertical movements of Spitsbergen. Przegl. Geogr. 31 (Suppl.), 143-178.

Landvik, J. Y. \& Salvigsen, O. 1985: Glaciation development and interstadial sea-level on central Spitsbergen, Svalbard. Polar Research 3 n.s., 1-10.

Salvigsen, O. 1981: Radiocarbon dated raised beaches in Kong Karls Land, Svalbard, and their consequences for the glacial history of the Barents Sea area. Geogra. Ann. 63A, 283-291.

Werenskiold, W. 1922: Høie strandlinjer paa Spitsbergen. Nor. Geol. Tidsskr. VII (I), 7-12

Zalewski, S. M., Kowalewski, W., Rudowski, S. \& Rossa, W. 1984: Preliminary results of seismoacoustic sounding of sea sediments in the region of Spitsbergen. Sympozjum Spitsbergen '84. Inst. Ekologii PAN, 12. 